\title{
SCIENTIFIC REPORTS

\section{Bacillus spp. characterization and his intervention as a possible non- traditional etiology of chronic renal insufficiency in Tierra Blanca, Veracruz, Mexico}

\author{
T. A. Quiñones-Muñoz $\mathbb{D}^{1 *}$, A. M. Villares-Bueno ${ }^{2}$, G. Hernández-Ramírez ${ }^{2}$, \\ R. Hernández-Martínez $\mathbb{B}^{3}$, M. A. Lizardi-Jiménez $\mathbb{D}^{4}$ \& V. Bocanegra-García ${ }^{5}$
}

Environmental, socioeconomic, educational, custom, occupation, and native pathogen microbiota factors have been identified as unique etiological factors by region for chronic renal insufficiency (CRI). In the region of Tierra Blanca, Veracruz, there is a significant incidence of CRI. The objective of this research was to identify the presence of the genus Bacillus spp. and its kinetic characterization for recognition as a possible non-traditional etiology of CRI in the region. The methodology included the isolation and morphological, biochemical, molecular and kinetic characterization of strains of the genus Bacillus spp. and an analysis of factors that indicate that their presence could affect the occupational health of the population, prompting cases of CRI. The presence of Bacillus cereus (pathogenic strain for humans) was established (biochemical identification, similarity $99 \%$, by $16 \mathrm{~S}$ rRNA gene) in sugarcane crops, mainly in the MEX-69-290 variety, with the higher growth rate and lower lag phase, compared to the other isolates. The strains are reported as a potential danger of direct infection and a risk factor for the indirect development of CRI, in the non-traditional cause modality, in the sugarcane fields. It is recommended that committed actions be undertaken to protect and promote the health of the population.

Chronic kidney insufficiency (CRI) is defined as kidney damage or a glomerular filtration rate lower than $60 \mathrm{~mL} /$ min per $1.73 \mathrm{~m}^{2}$ for three months, greater urinary albumin excretion, or both ${ }^{1} .8-16 \%$ of the population worldwide is affected by CRI ${ }^{2}$. Hypertension, diabetes mellitus, which causes $31 \%$ of cases of CRI due to diabetic nephropathy according to Rajapurkar et al. ${ }^{3}$, urinary tract infections, obesity, and smoking, have been reported as important risk factors for the presence of microalbuminuria (an indicator of kidney injury, between 30 and $300 \mathrm{mg}$ in $24 \mathrm{~h})^{4}$. CRI is considered as a serious threat, as it is usually detected in an advanced state, it is irreversible, and besides increasing the possibility of death, CRI is costly to treat and consumes financial resources at an alarming rate.

In addition to the underestimation of cases of CRI, it has been reported that its incidence and prevalence, along with other diverse pathologies, differ substantially across different countries and regions ${ }^{2}$, indicating that

\footnotetext{
${ }^{1}$ Consejo Nacional de Ciencia y Tecnología (CONACYT) - Centro de Investigación y Asistencia en Tecnología y Diseño del Estado de Jalisco, A.C. (CIATEJ) (Centro de Investigación y Desarrollo en Agrobiotecnología Alimentaria, CIDEA). Ciudad del Conocimiento y la Cultura de Hidalgo. Boulevard Santa Catarina S/N, Santiago Tlapacoya, San Agustín Tlaxiaca, Hidalgo, CP. 42163, México. ${ }^{2}$ Tecnológico Nacional de México/I.T. Superior de Tierra Blanca, Av. Veracruz. S/N, Col. PEMEX, Tierra Blanca, Veracruz, C.P. 95180, México. ${ }^{3}$ Consejo Nacional de Ciencia y Tecnología (CONACYT) - Colegio de Postgraduados. Campus Córdoba. Laboratorio de Biotecnología Microbiana. Km. 348 Carretera Federal Córdoba-Veracruz, Congregación Manuel León, Municipio de Amatlán de los Reyes, Ver., C.P. 94946, México. ${ }^{4}$ Consejo Nacional de Ciencia y Tecnología (CONACYT) - Universidad Autónoma de San Luis Potosí, Sierra Leona 550, Lomas 2da Secc., 78210, San Luis Potosí, México. Instituto Politécnico Nacional (IPN). Centro de Biotecnología Genómica. Boulevard del Maestro. S/N, esq. Elías Piña, Col. Narciso Mendoza, Reynosa, Tamaulipas, C.P. 88710, México.*email: dctanniaquinones@hotmail.com
} 
environmental, socio-economic factors, education, customs, and occupation can also affect the development of pathologies. This idea has been described as the presence of unique etiological factors ${ }^{5}$ of non-traditional origin (ERCnt) ${ }^{6}$, which are specific causes by region. In fact, the $\mathrm{WHO}^{7}$ refers to the presence of foodborne diseases as a regional issue, not being able to report worldwide estimates regarding bacteria and chemical agents as direct causes. In addition to the already identified traditional, and more common causes, of CRI, there may be non-traditional causes (of unknown etiology) in some regions, such as herbal and environmental toxins, the presence of heavy metals, and consumption of contaminated water. Besides these possible causes, an overlap of diseases has been detected, with a prevalence of infectious diseases and an increasing prevalence and severity of disorders due to unhealthy lifestyle factors, such as obesity, diabetes, and hypertension, as well as CRI. The development of diseases overlap has been attributed to accelerated urbanization and globalization processes involved in the transformation of countries, as has been reported for South Asia and Latin America ${ }^{2}$.

Studies have reported that cases of advanced CRI (stage V), without identified causes, appear in younger individuals, as well as economically vulnerable individuals, compared to cases with identified causes of the disease $^{3}$. It has also been reported that the cause or causes of kidney disease in young farmers, in productive ages, (outstanding group) in Sri Lanka and India have not been identified ${ }^{5}$. Other infections that cause severe kidney injury are hepatitis B and C viruses. Hepatitis $\mathrm{C}$ is a common comorbidity in kidney transplant recipients with end-stage renal disease, as $2.8 \%$ of kidney transplant patients were diagnosed with hepatitis $\mathrm{C}$ before transplantation $^{8}$. According to Asinobi et al. ${ }^{9}$ renal disease is an important extrahepatic manifestation of hepatitis B. These authors observed a pattern of kidney disease in children (3-15 years of age) with hepatitis B, with a predominance of nephrotic syndrome, followed by glomerulonephritis non-nephrotic, end-stage renal disease, and acute kidney injury in children ( 24 children) seen in a hospital in southwestern Nigeria.

Kidney damage is also a complication of endocarditis, usually caused by a bacterial infection, particularly Streptococcus and Staphylococcus, of the endocardial surface of the heart ${ }^{10}$. Bacterial groups (called vegetations) can form and break off and travel to other parts of the body, such as the lungs, brain, abdominal organs, kidneys, and limbs, causing various serious complications, including kidney damage ${ }^{11}$. A study in China comprising 401 patients with infective endocarditis showed that 202 patients $(50.4 \%)$ had positive microbial cultures, including Streptococcus (49.5\%), Staphylococcus (28.7\%), Enterococci (5.0\%), Gram-negative Bacilli (10.9\%), and others (Gram-positive Bacillus subtilis, Candida glabrata, Leuconostoc, Pseudomonas maltophilia, and Micrococcus kristinae). The rate of positive microbial cultures from patients in the renal failure group was higher than in the normal renal function group $(75 \%$ versus $46 \%, p<0.001)$. The incidence of streptococcal infection in the group with renal failure was higher than in the group with normal renal function $(71.4 \%$ versus $43.8 \%, p=0.001)$, but there were no significant differences between the two groups in the infection rates with Staphylococcus, Enterococcus and Gram-negative Bacilli between the two groups $(p>0.05)^{1}$.

With this background, we can visualize a possible relationship between microbial infections and the risk of developing CRI. A relationship is inferred mainly due to the presence of immunological problems that cause systemic disorders that lead to a greater development of stress (with thermal or hydric changes, which directly affect kidney insufficiency), as well as the development of diseases whose complications end in kidney damage. The genus Bacillus spp. are of importance, as they have been reported as opportunistic pathogens causing diseases, such as endocarditis and endophthalmitis ${ }^{12}$, and as already reviewed, there may be a relationship between its presence and transmission to humans, regarding the immunity and renal health.

There is experimental evidence that plants are able to control the composition of their microbiota and recruit effective protective pathogenic microorganisms in their rhizosphere or endorse ${ }^{13}$. Of the bacteria identified in the rhizosphere of sugarcane, Bacillus spp. excels. Bacillus spp. has the capacity to degrade hydrocarbons, such as benzopyrene ${ }^{14}$, and act as a bioinsecticide against lepidoptera ${ }^{15}$. Bacillus spp. can also act as a biocontrol agent, growth promoter (hormones), phosphate solubilizer, and nitrogen fixative ${ }^{16}$, as well as a phytopathogen ${ }^{17}$, and antibiotics producer for Bacillus subtilis ${ }^{18}$. The nitrification mechanisms, nitrogen fixation, facultative lithotrophy, and the acidophilic, alkalophilic, thermophilic and parasitic characteristics exemplify the ability of this genus to survive in diverse environments, as well as being able to exert diverse effects based on the context in which it is presented (e.g., substrate degrader) ${ }^{19}$, including the ability to cause human infections with affectations to the immune system.

In the genus Bacillus, the pathogens of importance regarding transmission are Bacillus cereus ${ }^{20}$, Bacillus anthracis ${ }^{21}$, Bacillus subtilis, and Bacillus licheniformis, which can be found in soil ${ }^{22}$, dust, and the gastrointestinal tract of animals and man. Some clinical manifestations have been identified by diarrhoeal and emetic toxins of Bacillus cereus, such as bovine mastitis, severe and systemic pyogenic infections, gangrene, septic meningitis, cellulitis, pulmonary abscesses, infant death and endocarditis. Bacillus subtilis and Bacillus licheniformis produce highly thermostable toxins, similar to the emetic toxin of Bacillus cereus ${ }^{23}$.

Isolates related to Bacillus mojavensis (REN4 and CEN2), Bacillus amyloliquefaciens (CEN6), Bacillus subtilis (CEN3), and Bacillus cereus (REN3 and CEN5), were obtained from the rhizosphere and endorized from plants in rice rotation (REN4 and REN3), clover (CEN6 and CEN2), and rapeseed (CEN5 and CEN3), in which antifungal activity was detected for rice crops ${ }^{13}$. In biocontrol ${ }^{16}$, the mechanism of action of Bacillus spp. is complex, as the genetic basis of control is not yet fully known. Bacillus spp. B25 is an effective control agent against the phytopathogenic fungus Fusarium verticillioides (Fv), with protease, glucanase, chitinase, and siderophore activities. The closely related species of the genus are Bacillus cereus, Bacillus thuringiensis and Bacillus anthracis, with a genetic relationship of $45-52 \%{ }^{24}$.

Occupational health and environmental risk factors are considered important in the prevention of ERC $\mathrm{nt}^{6}$; the sugarcane activity is significant in the study region, from that point of view. Sugarcane activity has several analysis fronts: contamination of water by chemical compounds that result from the cultivation and harvesting of sugarcane, burning sugarcane and the release of its emissions to the atmosphere, and the microorganisms of the rhizosphere that are potentially pathogenic to humans. So far in 2019 (July 31, 2019), 843,650 hectares of sugar 
cane were cultivated in Mexico, of which 57,923,011 tons were produced. Veracruz is the state with the highest production of sugarcane in the country, which produced $7,734,477$ tons so far in $2019^{25}$ with 85,377 hectares harvested, so far in 2019 (preliminary as of July 31). The rhizosphere of cane is an environment rich in different nutrients due to radical exudates, such as organic acids, carbohydrates, and amino acids, which makes it a rich ecosystem for the growth of a diversity of microorganisms, including bacteria ${ }^{26}$.

The presence of the genus Bacillus spp. in the root of sugarcane crops could be an indirect etiological factor of CRI, which in symbiosis with other factors, may be promoting the high incidence of the disease in the area of Tierra Blanca, Veracruz. The objective of this research was to isolate, identify and characterize strains of the genus Bacillus native to sugarcane fields as evidence of its presence in regions with a high prevalence of CRI and as evidence that it could be acting as one of several etiologies of the disease.

\section{Results and discussions}

Isolation of native strains. The Ingenio La Margarita S.A. of C.V., provided three different varieties of cane plants (COLMEX, CP-72-2086, MEX-69-290), of which the geographic location was registered (COLMEX, Lote Tempranero-Guapinole, coordinates N18 $30^{\prime} 47.3^{\prime \prime}$ W096 $26^{\prime} 08.1^{\prime \prime}$; CP-72-2086, Lote Tempranero-Buena Vista, coordinates N18 ${ }^{\circ} 30^{\prime} 40.2^{\prime \prime}$ W096 $26^{\prime} 58.5^{\prime \prime}$; MEX-69-290, Lote Tardío-Guapinole, coordinates N18 $30^{\circ} 50.8^{\prime \prime}$ W096 $\left.26^{\prime} 31.9^{\prime \prime}\right)$. Two of these varieties (CP-72-2086 and MEX-69-290), according to a technical report by SAGARPA $^{27}$, are the most used in the country, covering $65 \%$ of the national surface. Thus, these varieties are representative of the type of cane produced in the country.

After a visual inspection of the sugarcane seedlings, it was determined that they were healthy, and no pests were present. Once the health of the seedlings was verified, portions of the root were removed, while avoiding fracturing the plant and having as little direct contact with them as possible. The cultures obtained from the root of the plants presented colonies with morphological characteristics belonging to the genus Bacillus spp., such as a dry or creamy consistency, as wells as a concentric ring and irregular border in the center, as described by Calvo and Zúñiga ${ }^{28}$ and Larrea-Izurieta et al. ${ }^{17}$. We obtained four different isolates, three from the MEX-69-290 (MEX01-A, MEX-03-C, MEX-04-C) and one from CP-72-2086 (CP-01-C). No isolates were obtained from the seedling of the COLMEX variety. García et al. ${ }^{29}$ sampled the rhizosphere of sugarcane from different areas of the state of Tamaulipas, where 121 bacterial strains were isolated, of which 19 strains presented morphological characteristics to the genus Bacillus spp. Additionally, the authors reported that most of the samples were obtained from fields with old agricultural management (50 years).

Kinetic characterization: growth kinetics. The determination of radial growth, in vitro, for microorganisms is considered subjective and dependent on the subject who performs the experiment; thus, the calculation of kinetic parameters is recommended to obtain more reliable data. Therefore, an adjustment was made to the Gompertz model and the corresponding kinetic parameters were determined.

We sought to obtain growth description parameters of the isolated strains to support the determination of concentrations and times considered to be of danger to humans, which could result in infections that endanger health and life. In addition, the identification of growth phases, according to previous data ${ }^{16}$, can indicate the type of danger that can occur (for example, Bacillus cereus is enterotoxic in the exponential phase of growth ${ }^{12}$ ). The high $\mu_{\max }$ values indicate a higher growth rate, and therefore a higher microorganism concentration in the medium, which would increase the risk of infection. Besides being able to identify risks, determining growth curves allow for the establishment of culture conditions for the use of metabolites, such as enzymes or antibiotics produced by the isolates. In the case of the genus Bacillus spp., which has pathogenic microorganisms, to understand its growth curves, together with thermal death curves, will support the development of pasteurization and control conditions, or technologies, to avoid economic losses due to its capacity to produce heat-resistant spores and its ability to grow in refrigerated foods ${ }^{16}$.

The initial cell count was performed in the Neubauer chamber, obtaining a concentration of $1 \times 10^{7}$ cells $/ \mathrm{mL}$, for inoculum. The subsequent counts, which were performed every $2 \mathrm{~h}$ for $12 \mathrm{~h}$ of the growth under the established culture medium, showed results that were analyzed using the Gompertz mathematical model. The culture medium was supplemented with sugarcane bagasse, molasses, and yeast extract (as a nitrogen source) to observe how the strains behave in a medium containing material similar to that found naturally in the sugarcane fields and to consider the nutritional needs of the genus. Using the formulated medium, the basic needs of the microorganism were complete for its growth and characterization. The limitation of nutrients can cause a decoupling of catabolic and anaerobic processes that would decrease the yield of the biomass, as well as modify the cellular physiology.

In the supplemented medium, growth was faster compared to growth in a standard medium (only sterile water). Isolates MEX-01-A and MEX-03-C showed the highest $\mu_{\max }\left(0.99 \mathrm{~h}^{-1}\right.$ and $1.03 \mathrm{~h}^{-1}$, respectively) and the lowest lag phases $\left(0.37 \mathrm{~h}^{-1}\right.$ and $0.27 \mathrm{~h}^{-1}$, respectively), which makes them potent pathogens, with a greater potential to grow in shorter times (Table 1). The inflection times determined by modeling (Ti) (Fig. 1), indicated the strains that reached the end of the logarithmic phase in less time were MEX-01-A $(1.71 \mathrm{~h})$ and MEX-03-C $(1.70 \mathrm{~h})$, which could signify the time needed to produce toxic substances, as well as the time of greatest risk of toxicity. Espinoza ${ }^{30}$ reported growth kinetics of Bacillus subtilis in Schaeffer medium supplemented with glucose, in which the microorganism presented a $\mu_{\max }$ of $1.76 \mathrm{~h}^{-1}$ and a lag phase of $0 \mathrm{~h}$ (aerobic condition). The differences found between the kinetic parameters can be due to the type of medium (carbon and nitrogen sources) in which the kinetics were developed, if the carbon source is easy to assimilate or not, or the temperature, variables that directly influence the registered results. Bacillus subtilis has been reported as one of the species with the highest rates of growth and death ${ }^{16}$. 


\begin{tabular}{|l|l|l|l|l|l|l|}
\hline \multirow{2}{*}{ Strain } & \multicolumn{3}{|l|}{ Simple growing medium } & \multicolumn{3}{l|}{ Supplemented culture medium } \\
\cline { 2 - 7 } & $\mathbf{L a g}(\mathbf{h})$ & $\mathbf{T i}$ & $\boldsymbol{\mu}_{\max }\left(\mathbf{h}^{-1}\right)$ & $\mathbf{L a g}(\mathbf{h})$ & $\mathbf{T i}$ & $\boldsymbol{\mu}_{\max }\left(\mathbf{h}^{-1}\right)$ \\
\hline MEX-01-A & 0.47 & 2.29 & 1.01 & 0.37 & 1.71 & 0.99 \\
\hline MEX-03-C & 0.00 & 1.92 & 0.77 & 0.27 & 1.70 & 1.03 \\
\hline MEX-04-C & 0.09 & 2.31 & 0.83 & 0.73 & 2.54 & 0.91 \\
\hline CP-01-B & 0.75 & 3.25 & 0.88 & 0.50 & 2.29 & 1.03 \\
\hline
\end{tabular}

Table 1. Growth kinetic parameters in simple and supplemented culture medium ( $2 \%$ sugarcane bagasse, $1 \%$ yeast extract, and $1 \%$ molasses). Lag (h): Lag pase time, in hours. Ti: Inflection time, in hours. $\mu_{\max }\left(\mathrm{h}^{-1}\right)=$ Specific maximum growth rate, in $1 /$ hour $\left(\mathrm{h}^{-1}\right)$.

\begin{tabular}{|l|l|l|l|l|l|l|l|}
\hline Isolated strain & $\begin{array}{l}\text { Gram } \\
\text { staining }\end{array}$ & Catalase & $\begin{array}{l}\text { Methyl } \\
\text { red }\end{array}$ & $\begin{array}{l}\text { Voges- } \\
\text { Proskauer }\end{array}$ & $\begin{array}{l}\text { Citrate } \\
\text { reduction }\end{array}$ & $\begin{array}{l}\text { Growth in } \\
\text { NaCl 7\% }\end{array}$ & $\begin{array}{l}\text { Starch } \\
\text { hydrolysis }\end{array}$ \\
\hline Gender reference Bacillus spp. & $+^{46}$ & $+^{32}$ & $+^{47}$ & $+{ }^{17}$ & $+^{42}$ & $+{ }^{28}$ & $+^{43}$ \\
\hline MEX-01-A & + & + & + & + & - & + & + \\
\hline MEX-03-C & + & + & + & + & - & + & + \\
\hline MEX-04-C & + & + & + & + & - & + & + \\
\hline CP-01-B & + & + & + & + & - & + & + \\
\hline
\end{tabular}

Table 2. Biochemical tests for bacterial strains.

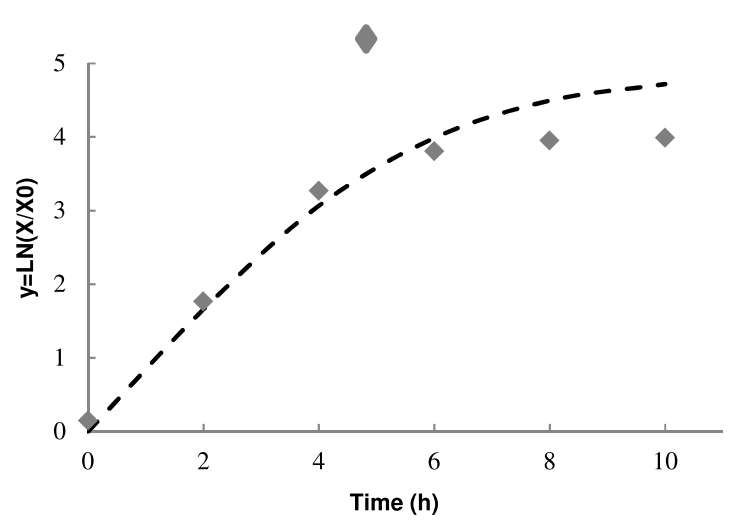

Figure 1. Growth of the MEX-03-C strain ( $)$ in sterile water supplemented with $1 \%$ molasses, $1 \%$ yeast extract and $2 \%$ bagasse of cane. A 2-h count was performed with a Neubauer chamber (viable cells $/ \mathrm{mL}$ ). The growth data obtained were adjusted to the Gompertz model $(\cdot)$, to obtain the corresponding kinetic parameters $\left(\mu_{\max }, \lambda\right)$.

Biochemical identification. Biochemical tests were performed on the strains with morphological features characteristic of the genus Bacillus spp. and compared with the antecedents ${ }^{31-33}$. The results indicate a positive behavior to the gender. Table 2 shows the results for each strain as well as the base reference. All strains isolated and analyzed based on morphology tested positive for the genus Bacillus spp.

A declaration of identification by species requires molecular analysis. Bacillus cereus and Bacillus thuringiensis, are biochemically identical, differing only in the production of the parasporal crystal (BBL CRYSTAL). Therefore, the biochemical tests were not definitive for determining the species of the strains; although, they have presented broad characteristics for the genus ${ }^{34}$.

Molecular identification. DNA extraction and quantification were performed on the kinetic-identified strains as the most dangerous to the nearby population (latent pathogens). Both the sufficiency and purity of the samples were verified before continuing with molecular identification of the morphologically and biochemically identified strains of the Bacillus genus. Electrophoresis showed bands of DNA from each of the strains that corresponded to the V4 region of the $16 \mathrm{~S}$ rRNA gene that we wished to amplify, with $510 \mathrm{bp}$. When the molecular weight patterns of strains show different bands, this indicates different molecular weights, a characteristic called polymorphism ${ }^{34}$.

The isolated bacterial strains had a high percentage of similarity in the BLAST (Basic Local Alignation Search Tool) search of the NCBI (National Center for Biotechnology Information) with the corresponding sequences available (Table 3) Program BLASTN 2.8.135,36). Strain MEX-01-A presented the highest quantity of nucleic acids with an optimum purity for its replication. Based on the results, with $99 \%$ similarity it was confirmed that the isolated bacterial strains correspond to the Bacillus genus, with B. anthracis and B. cereus being the microorganisms 


\begin{tabular}{|c|c|c|c|c|c|c|c|}
\hline Strain & Closest Match (Description) & $\begin{array}{l}\text { Max } \\
\text { score }\end{array}$ & $\begin{array}{l}\text { Total } \\
\text { score }\end{array}$ & $\begin{array}{l}\text { Query } \\
\text { Coverage (\%) }\end{array}$ & E value & Identity & Accession No. \\
\hline \multirow{2}{*}{ MEX-01-A } & $\begin{array}{l}\text { Bacillus anthracis } 16 \mathrm{~S} \text { ribosomal RNA } \\
\text { gene, partial sequence }\end{array}$ & 795 & 795 & $95 \%$ & 0.0 & $99 \%$ & KP126519.1 \\
\hline & $\begin{array}{l}\text { Bacillus cereus partial 16S rRNA gene, } \\
\text { isolate BCsn }\end{array}$ & 795 & 795 & $95 \%$ & 0.0 & $99 \%$ & HE660034.1 \\
\hline \multirow{2}{*}{ MEX-03-C } & $\begin{array}{l}\text { Bacillus cereus strain ST06 16S } \\
\text { ribosomal RNA gene, partial sequence }\end{array}$ & 880 & 880 & $100 \%$ & 0.0 & $99 \%$ & MF496242.1 \\
\hline & $\begin{array}{l}\text { Bacillus anthracis strain Larisa } 16 \mathrm{~S} \\
\text { ribosomal RNA gene, partial sequence }\end{array}$ & 880 & 880 & $100 \%$ & 0.0 & $99 \%$ & MH135297.1 \\
\hline \multirow{2}{*}{ MEX-04-C } & $\begin{array}{l}\text { Bacillus cereus strain YB37 16S } \\
\text { ribosomal RNA gene, partial sequence }\end{array}$ & 187 & 187 & $61 \%$ & $3 e-43$ & $77 \%$ & KJ720024.1 \\
\hline & $\begin{array}{l}\text { Bacillus thuringiensis strain } 3 \mathrm{~S}^{-1} 16 \mathrm{~S} \\
\text { ribosomal RNA gene, partial sequence }\end{array}$ & 182 & 182 & $61 \%$ & $1 e-41$ & $76 \%$ & MG738339.1 \\
\hline \multirow{2}{*}{ CP-01-B } & $\begin{array}{l}\text { Bacillus sp. EF4A-B854 16S ribosomal } \\
\text { RNA gene, partial sequence }\end{array}$ & 861 & 861 & $80 \%$ & 0.0 & $99 \%$ & KC545277.1 \\
\hline & $\begin{array}{l}\text { Bacillus sp. RKBH-B153 16S ribosomal } \\
\text { RNA gene, partial sequence }\end{array}$ & 861 & 861 & $80 \%$ & 0.0 & $99 \%$ & JX317730.1 \\
\hline
\end{tabular}

Table 3. Molecular similarity of isolated strains and Gen Bank records (the largest Query Coverage (\%) are presented).

identified for that strain (Table 3). The presence of Bacillus anthracis for the strains MEX-01-A and MEX-03-C has been found with high similarity ( $99 \%$ for both). More than $99 \%$ sequence similarity of the primary structure of 16S rRNA has been recorded between Bacillus cereus, Bacillus anthracis, Bacillus mycoides, and Bacillus thuringiensis. Based on the similarity between them, including phenotypic and genotypic properties, all have been considered Bacillus cereus varieties ${ }^{12}$.

Bacillus cereus is commonly found in the environment and has the potential to contaminate food due to poor manufacturing practices (in processing or at home) ${ }^{20}$. Bacillus cereus can cause diarrhoeal and emetic syndrome with concentrations ranging from $10^{3}-10^{7}$ cells or spores, although the exact dose response has not yet been established as described by Santa María et al. ${ }^{37}$. Bacillus cereus AMSB3 has also been reported as an Manganese solubilizer according to Sanket et al. ${ }^{38}$, together with Bacillus nealsonii AMSB4, Enterobacter spp. AMSB1, and Staphylococcus hominis AMSB5.

Bacillus cereus has been recognized as a bacterium of clinical importance, not only as an environmental pollutant, as it can spread to any system of food production and processing, easily infecting humans and causing affectations of health and deterioration of the immune system, along with all the consequences. Its ability to form endospores gives it the advantage of surviving in extreme conditions, such as high temperatures, even during pasteurization; it produces seven types of toxins, cereulide (emetic toxin), three enterotoxins (hemolysin BL or HBL, non-hemolytic or NHE and enterotoxin T or EntT; responsible for emetic and diarrhoeal syndrome), and three phospholipases (poisoning generators). Additionally, its affectations may not be so well identified due to the high similarities in the symptoms it causes with other strains of the genus, such as Bacillus thuringiensis, which is widely used as an insecticide in agriculture ${ }^{12}$.

From the results obtained, a pathological danger is identified in sugarcane fields that could be indirectly causing the development of diseases, such as CRI, through mechanisms of infection, immunological problems, and symbiosis with other etiologies of the disease. The presence of Bacillus cereus in MEX-69-290, one of the most cultivated of sugarcane varieties, indicates a strong possible effect on labor in the fields.

The presence of Bacillus cereus, recognized as a pathogenic strain, has been established in sugarcane crops in the region of Tierra Blanca, Veracruz, mainly in the MEX-69-290 variety, which is one of the most sown and harvested in the State of Veracruz and the country. Morphological and biochemical analyses confirmed that the isolated strains belong to the genus Bacillus. Strains of Bacillus spp. isolated from the cane root variety MEX-69-290, presented a higher growth rate with respect to the CP-72-2086 variety; so, they are reported as a potential danger of direct infection and an indirect risk factor for the development of CRI in the non-traditional cause modality. Two strains were identified molecularly as Bacillus cereus, with a 99\% similarity rate, and four as part of the genus with similarities from 76\%, between the sequences detected by the amplification of the $16 \mathrm{~S}$ rRNA gene and those in the Gen Bank database.

\section{Methods}

Sampling. The plants were donated by "Ingenio La Margarita S.A. of C.V." from the fields of the same processor. Three plants from different sugarcane varieties were randomly collected and their geospatial location (longitude and latitude) was recorded.

Bacteria isolation. $1 \mathrm{~g}$ of the root of the sugarcane seedlings was taken and added to tubes with $9 \mathrm{~mL}$ of peptonated water in a $1 / 10$ ratio $(\mathrm{w} / \mathrm{v})$, incubated at $65^{\circ} \mathrm{C}$ for $24 \mathrm{~h}$, and then transferred to $4{ }^{\circ} \mathrm{C}$ for $20 \mathrm{~min}$ (thermal shock to control the growth of genera other than Bacillus spp.). Serial dilutions were made from $10^{-1}$ to $10^{-5}$, of which the $10^{-1}, 10^{-3}$, and $10^{-5}$ dilutions were seeded by stria onto plates with nutritive agar. The cultures were maintained at $35^{\circ} \mathrm{C}$ for $24 \mathrm{~h}$. The colonies with different morphologies were isolated from the culture to obtain unique strains with homogeneous morphological characteristics based on the appearance of the shape, edge, surface, size, consistency, color, and elevation. A number was assigned to each strain isolated from the cane seedlings for their correct identification (modified from Carreras ${ }^{39}$ ). 
Morphological characterization of the isolated bacteria. The morphological characterization of strains for the genus Bacillus spp. was carried out based on the following: Colonies with irregular shape, serrated or finger-like borders, whitish or cream, acuminate or flat elevations ${ }^{28}$, and floury, waxy, dry or creamy appearance $^{17}$.

Bacteria biochemical characterization. Considering the strains with positive morphological tests for the genus Bacillus spp., the following confirmatory tests were performed for the biochemical identification of the genus: Gram-positive [Gram stain ${ }^{(31)}$, catalase positive ${ }^{17}$, Voges Proskauer-Methyl Red (MR-VP) positive ${ }^{40}$, citrate positive ${ }^{41}$, Triple Sugar Iron Agar test, Starch hydrolysis ${ }^{17,42}$, survival at $7 \%$ in $\mathrm{NaCl}^{43}$, and Anaerobiosis $(-/+)$ survival at $50^{\circ} \mathrm{C}^{28}$.

Kinetic characterization of strains by growth curves. A hoe was taken from each strain and inoculated into the selected culture media, to measure growth: (1) simple sterile water and (2) sterile water supplemented with $1 \%$ molasses, $1 \%$ yeast extract and $2 \%$ bagasse of cane. The samples were incubated at $35^{\circ} \mathrm{C}$ for $24 \mathrm{~h}$. Next, a suspension was prepared, where $250 \mathrm{~mL}$ Erlenmeyer flasks containing previously sterilized media $\left(121^{\circ} \mathrm{C}\right.$ for $15 \mathrm{~min}$ ) were inoculated with $1 \times 10^{7} \mathrm{cells} / \mathrm{mL}$, and the cells were maintained at $35^{\circ} \mathrm{C}$, with agitation/aeration. A 2-h count was performed with a Neubauer chamber (viable cells $/ \mathrm{mL}$ ). The growth data obtained were adjusted to the Gompertz model, to obtain the corresponding kinetic parameters $\left(\mu_{\max }, \lambda\right)$. This mathematical model was designed to describe growth, which helps interpret a phenomenon under controlled conditions. The model is expressed with the reparametrized Gompertz equation for sigmoidal growth by mathematical parameters, a, b, c (Eq. 1), where the specific maximum growth rate $\left(\mu_{\max }\right)$ is defined as the tangent at the inflection point (Eq. 2). The lag phase $(\lambda)$ is defined as the intercept of the $\mathrm{x}$-axis in the tangent (Eq. 3$)^{44}$.

$$
\begin{gathered}
y=A \exp \left\{-\exp \left[\frac{\mu_{\text {max }} e}{A}(\lambda-t)+1\right]\right\} \\
\mu_{\text {max }}=(d y / d t)_{t_{i}}=\frac{a c}{e} \\
\lambda=\frac{(b-1)}{c}
\end{gathered}
$$

Molecular identification of microorganisms. Strains propagation. The microorganisms were stored in tubes containing sterile water, under refrigeration. For activation of the strains, each bacterial strain was plated on tryptic soy agar (TSA) $\left(35^{\circ} \mathrm{C}\right.$ for $\left.24 \mathrm{~h}\right)$ to obtain pure colonies.

Obtaining DNA. The Wizard ${ }^{\circledR}$ Genomic DNA purification kit was used according to the manufacturer's instructions. The quantification (ng/ $\mu \mathrm{L}$ sample) and evaluation of nucleic acid purity was performed using a spectrophotometer (UV-vis) NanoDrop by placing $2 \mu \mathrm{L}$ of sterile water as the target and $2 \mu \mathrm{L}$ of the samples ${ }^{4}$.

Molecular identification. Polymerase chain reaction (PCR) was carried out in an Applied Biosystems ${ }^{\circledR}$ thermocycler. For amplification of the V4 region of the $16 \mathrm{~S}$ rRNA gene, the mixture contained: $5.63 \mu \mathrm{L}$ of water, $3 \mu \mathrm{L}$ of $5 \mathrm{X}$ buffer, $1.1 \mu \mathrm{L}$ of $50 \mathrm{mM}$ magnesium chloride $\left(\mathrm{MgCl}_{2}\right), 0.4 \mu \mathrm{L}$ of dNTPs, $0.9 \mu \mathrm{L}$ of PF and PR, $0.07 \mu \mathrm{L}$ of Taq polymerase, $3 \mu \mathrm{L}$ of the bacterial lysate (isolated DNA), in a final volume of $15 \mu \mathrm{L}$. The following settings were used for the amplification program: a denaturation cycle of $4 \mathrm{~min}$ at $95^{\circ} \mathrm{C}$, followed by 30 cycles of denaturation for $30 \mathrm{~s}$ at $95^{\circ} \mathrm{C}$, an alignment cycle of $30 \mathrm{~s}$ at $53^{\circ} \mathrm{C}$, an extension cycle for $30 \mathrm{~s}$ at $72^{\circ} \mathrm{C}$, and a final extension for $5 \mathrm{~min}$ at $72^{\circ} \mathrm{C}^{34}$. To purify the amplified product, the Kit Wizard ${ }^{\circledR}$ SV Gel and PCR Clean-Up System was used according to the manufacturer's instructions. Sequencing was performed in Eurofins Genomics (https://www. eurofinsgenomics.com/en/home/), and the sequences obtained were analyzed using the NCBI database (https:// www.ncbi.nlm.nih.gov/).

\section{Data availability}

The datasets generated during and/or analyzed during the current study are available from the corresponding author on reasonable request.

Received: 7 October 2019; Accepted: 18 February 2020;

Published online: 09 March 2020

\section{References}

1. Liu, Y. et al. Risk factors and short-term prognosis of preoperative renal insufficiency in infective endocarditis. J. Thorac. Dis. 10, 3679-3688 (2018).

2. Jha, V. et al. Chronic kidney disease: global dimension and perspectives. Lancet 382, 260-72 (2013).

3. Rajapurkar, M. M. et al. What do we know about chronic kidney disease in India: first report of the Indian CKD registry. BMC Nephrol. 13, 1-8 (2012).

4. Wanigasuriya, K. P., Peiris-John, R. J. \& Wickremasinghe, R. Chronic kidney disease of unknown aetiology in Sri Lanka: is cadmium a likely cause? BMC Nephrol. 12, 1-7 (2011)

5. Jha, V. Current status of chronic kidney disease care in southeast Asia. Semin. Nephrol. 29, 487-96 (2009).

6. Reveiz, L., Pinzón-Flórez, C., Glujovsky, D., Elias, V. \& Ordunez, P. Establecimiento de prioridades de investigación en la enfermedad renal crónica de causas no tradicionales en Centroamérica. Rev. Panam. Salud Pública. 42, 1-8 (2018). 
7. WHO. WHO estimates of the global burden of foodborne diseases: foodborne disease burden epidemiology reference group 2007-2015. (World Health Organization, 2015).

8. Radhakrishnan, R. C. et al. The long-term impact of hepatitis $C$ infection in kidney transplantation in the pre-direct acting antiviral era. Saudi J. Kidney Dis. Transpl. 29, 1092-1099 (2018).

9. Asinobi, A. O. et al. Kidney disease in hepatitis B surface antigen-positive children: experience from a centre in south-west Nigeria and a review of the Nigerian literatura. Paediatr. Int. Child Health 38, 16-22 (2018).

10. Hernández-Pérez, J. E., Domínguez-Trejo, G., Morales-Portano, J. D., Robles-Tenorio, A. \& Pérez-Cuadra, A. Mitral valve infective endocarditis associated with bacterial meningitis: case report. Rev. Mex.Cardiol. 29, 188-192 (2018).

11. Mayo Clinic. Mayo Foundation for Medical Education and Research (MFMER). https://www.mayoclinic.org (2018)

12. Pérez, P. I. Bacillus cereus y su papel en las intoxicaciones alimentarias. Rev. Cub. Salud Pública. 38, 98-108 (2012).

13. Etesami, H. \& Alikhani, H. A. Bacillus species as the most promising bacterial biocontrol agents in rhizosphere and endorhiza of plants grown in rotation with each other. Eur. J. Plant Patho. 150, 497-506 (2018).

14. Lily, M. K., Bahuguna, A., Dangwal, K. \& Garg, V. Degradation of benzo [a] pyrene by a novel strain Bacillus subtilis BMT4i (MTCC 9447). Braz. J. Microbiol. 40, 884-892 (2009).

15. Schünemann, R., Knaak, N. \& Fiuza, L. M. Mode of action and specificity of Bacillus thuringiensis toxins in the control of caterpillars and stink bugs in soybean culture. ISRN Microbiology, https://doi.org/10.1155/2014/135675 (2014).

16. Castañeda, A. E. \& Sánchez, L. C. Evaluación del crecimiento de cuatro especies del género Bacillus sp., primer paso para entender su efecto biocontrolador sobre Fusarium sp. NOVA. 13, 53-63 (2016).

17. Larrea-Izurieta, I., Falconí-Borja, C. \& Arcos-Andrade, A. Aislamiento y caracterización de cepas de Bacillus spp. con actividad contra Tetranychus urticae Koch en cultivos comerciales de rosas. Rev. Colomb. de Biotecnol. 17, 140-148 (2015).

18. Puri, A., Padda, K. P. \& Chanway, C. P. Plant growth promotion by endophytic bacteria in nonnative crop hosts. In: Endophytes: Crop Productivity and Protection. Sustainable Development and Biodiversity, 16. (Springer International Publishing AG, 2017).

19. Tejera-Hernández, B., Rojas-Badía, M. M. \& Heydrich-Pérez, M. Potencialidades del género Bacillus en la promoción del crecimiento vegetal y el control biológico de hongos fitopatógenos. Revista CENIC. Cien. Biol. 42, 131-138 (2011).

20. Sánchez, J., Correa, M. \& Castañeda-Sandoval, L. M. Bacillus cereus un patógeno importante en el control microbiológico de los alimentos. Rev. Fac. Nac. Salud Pública. 34, 230-242 (2016).

21. PAHO/OMS. a). Module 1: Terrorism in Perspective. Pan American Health Organization, https://www.paho.org/hq/index. php?option $=$ com_content\&view $=$ article\&id $=10838$ :2015-peligros-biologicos\&Itemid $=41432 \& l a n g=e n(2018)$.

22. Rodas, J. B. A., Quero, B. M., Magaña, S. H. F. \& Reyes, R. A. Selección de cepas nativas con actividad quitino-proteolítica de Bacillus sp. aisladas de suelos tropicales. Rev. Colomb. Biotecnol. 11, 107-113 (2009).

23. PAHO/OMS. b). Peligros biológicos. Pan American Health Organization, https://www.paho.org/hq/index.php?option=com_conte nt\&view=article\&id=10838:2015-peligros-biologicos\&Itemid=41432\&lang=en (2018).

24. Douriet-Gámez, N. R., Maldonado-Mendoza, I. E., Ibarra-Laclette, E., Blom, J. \& Calderón-Vázquez, C. L. Genomic analysis of Bacillus sp. strain B25, a biocontrol agent of maize pathogen Fusarium verticillioides. Curr. Microbiol. 75, 247-255 (2018).

25. SIAP. Sistema de Información Agroalimentaria y Pesquera, http://infosiap.siap.gob.mx:8080/agricola_siap_gobmx/ AvanceNacionalSinPrograma.do;jsessionid=107C9F66E770497AD5D0D9BD69877B63 (2019).

26. Yuan, J. et al. Roots from distinct plant developmental stages are capable of rapidly selecting their own microbiome without the influence of environmental and soil edaphic factors. Soil Biol. Biochem. 89, 206-209 (2015).

27. SAGARPA. Variedades con mejores rendimientos de las zonas cañeras en México. Nota Técnica Informativa. Secretaría de Agricultura, ganadería, desarrollo rural, pesca y alimentación, http://www.conadesuca.gob.mx (2016).

28. Calvo, P. \& Zuñiga, D. Caracterización fisiológica de cepas de Bacillus spp. aisladas de la rizósfera de papa (Solanum tuberosum). Ecol. Apl. 9, 31-39 (2010).

29. García, O. J. G., Reyes, H. J., Sánchez, V. A. \& García, D. M. A. Aislamiento y caracterización molecular de bacterias endófitas nativas de caña de azúcar (Sacharum officinarum L.) solubilizadoras de fósforo y fijadoras de nitrógeno. Preprint at https://www.atamexico. com.mx/wp-content/uploads/2017/11/8-NUTRICI\%C3\%93N-Y-SUELOS-2016.pdf (2016).

30. Espinoza, M. F. J. J. Caracterización del proceso de crecimiento de Bacillus subtilis bajo condiciones anaerobias. Dissertation. (Universidad Nacional Autónoma De México). Preprint at http://www.ibt.unam.mx/alfredo/JoelEspinosa.pdf (2005).

31. López-Jácome, L. E. et al. Las tinciones básicas en el laboratorio de microbiología. Investig Discapacidad. 3, 10-18 (2014).

32. Pérez-Portuondo, I., Orberá-Ratón, T. \& Tamayo-Núñez, J. L. Aislamiento e identificación de Bacillus cereus a partir de dos variantes de arroz comercial (Oryza sativa L.). Revista CENIC Cien. Biol. 42, 139-144 (2011).

33. Vidhya, R. \& Thatheyus, A. J. Biodegradation of dimethylformamide using Bacillus subtilis. Am. J. Microbiol. Res. 1, 10-15 (2013).

34. Galvis, F. \& Yolima, M. L. Caracterización molecular mediante rep-PCR de aislados nativos de Bacillus thuringiensis, obtenidos de muestras de suelo. Agronomía Costarricense. 38, 223-229 (2014).

35. Zhang, Z., Schwartz, S., Wagner, L. \& Miller, W. A greedy algorithm for aligning DNA sequences. J. Comput. Biol. 7, 203-14 (2000).

36. Morgulis, A. et al. Database indexing for production megaBLAST searches. Bioinform. 24, 1757-1764 (2008).

37. Santa María, M. S. et al. Perfil de riesgo Bacillus cereus en alimentos listos para consumo no industrializado. Preprint at https:// studylib.es/doc/4638823/perfil-bacillus-cereus-instituto-nacional-de-salud (2011).

38. Sanket, A. S., Ghosh, S., Sahoo, R., Nayak, S. \& Das, A. P. Molecular identification of acidophilic Manganese (Mn) solubilizing bacteria from mining effluents and their application in mineral beneficiation. Geomicrobiol. J. 34, 71-80 (2016).

39. Carreras, S. B. Obtención de aislados de Bacillus thuringiensis Berliner autóctonos de cuba. Fitosanidad, Ecología. 13, 109-115 (2009).

40. Snehalatha, V., Malashree, R. \& Soni, P. Isolation, enumeration and antimicrobial susceptibility of predominant microbes associated with currency notes. Int. J. Curr. Microbiol. App. Sci. 5, 650-657 (2016).

41. McFaddin, J. F. Biochemical Test for Identification of Medical Bacteria. 3rd. Ed. 1-912 (Lippincott Williams and Wilkins, 2000).

42. Reinoso, P. Y., Casadesús, R. L., García, S. A., Gutiérrez, P. J. \& Pazos, A. R. V. Aislamiento, selección e identificación de bacterias del género Bacillus antagonistas de Pectobacterium carotovorum. Fitosanidad, Diagnóstico. 10, 187-191 (2006).

43. Sosa, L. A. I., Pazos, A. R. V., Torres, C. D. \& Casadesús, R. L. Identificación y caracterización de seis aislados pertenecientes al género Bacillus sp. promisorios para el control de Rhizoctonia solani Künh y Sclerotium rolssii Sacc. Fitosanidad, Control biológico. 15, 39-43 (2011).

44. Valdivia-Rivera, S., Varela-Santos, E. C., Quiñones-Muñoz, T. A., Hernández-Martínez, R. \& Lizardi-Jiménez, M. A. Production of hydrocarbon-degrading microorganisms using agricultural residues of Mangifera indica L. and Carica papaya as carbon source. 3 Biotech. 9, 1-8 (2019).

45. Ruiz, B. et al. Extracción y cuantificación de ADN de pajillas de semen bovino crio preservado. Rev. Cien. UDO Agrícola. 10, 103-108 (2010)

46. Méndez-Úbeda, J. M., Flores, M. S. \& Paramo-Aguilera, L. A. Aislamiento e identificación de Bacillus subtilis y evaluación del antagonismo in vitro frente hongos fitopatógenos. Nexo Rev. Cien. 30, 96-110 (2017).

47. Badía, M. M. R., Hernández, B. T., Murrel, J. A. L., Mahillon, J. \& Pérez, M. H. Aislamiento y caracterización de cepas de Bacillus asociadas al cultivo del arroz (Oryza sativa L.). Rev. Bras. Agroecol. 6, 90-99 (2011). 


\section{Acknowledgements}

To the National Council of Science and Technology for the scholarship awarded to Alejandra María Villares Bueno (No. 616873-594640). To The Ingenio La Margarita for providing the sugarcane samples for the study.

\section{Author contributions}

Quiñones-Muñoz, T.A.: design of the work, the acquisition, analysis, or interpretation of data, produced the manuscript: morphological, biochemical and kinetic characterization, molecular identification. Villares-Bueno, A.M.: design of the work, the acquisition, analysis, or interpretation of data: sampling, bacteria isolation, morphological, biochemical and kinetic characterization, molecular identification. Hernández-Ramírez, G.: design of the work, the acquisition, analysis, or interpretation of data: sampling, morphological characterization, Hernández-Martínez, R.: design of the work, the acquisition, analysis, or interpretation of data, reviewed the manuscript: morphological and kinetic characterization, Lizardi-Jiménez, M.A.: design of the work, the acquisition, analysis, or interpretation of data, reviewed the manuscript: kinetic characterization, BocanegraGarcía, V.: the acquisition, analysis, or interpretation of data, reviewed the manuscript: molecular identification.

\section{Competing interests}

The authors declare no competing interests.

\section{Additional information}

Correspondence and requests for materials should be addressed to T.A.Q.-M.

Reprints and permissions information is available at www.nature.com/reprints.

Publisher's note Springer Nature remains neutral with regard to jurisdictional claims in published maps and institutional affiliations.

(c) (i) Open Access This article is licensed under a Creative Commons Attribution 4.0 International

License, which permits use, sharing, adaptation, distribution and reproduction in any medium or format, as long as you give appropriate credit to the original author(s) and the source, provide a link to the Creative Commons license, and indicate if changes were made. The images or other third party material in this article are included in the article's Creative Commons license, unless indicated otherwise in a credit line to the material. If material is not included in the article's Creative Commons license and your intended use is not permitted by statutory regulation or exceeds the permitted use, you will need to obtain permission directly from the copyright holder. To view a copy of this license, visit http://creativecommons.org/licenses/by/4.0/.

(c) The Author(s) 2020 